\title{
APLIKASI BENANG SLUB UNTUK PEMBUATAN BAHAN WINDOW COVERING
}

\author{
SLUB YARN APPLICATION \\ FOR MANUFACTURING WINDOW COVERING MATERIAL
}

\author{
Yusniar Siregar, M. Danny Sukardan, Dermawati Suantara, Rizal Fahruroji \\ Balai Besar Tekstil, Jalan Jenderal Ahmad Yani No. 390 Bandung \\ E-mail: texirdti@bdg.centrin.net.id
}

Tanggal diterima: 21 Oktober 2019, direvisi: 28 Desember 2019, disetujui terbit: 28 Desember 2019

\begin{abstract}
ABSTRAK
Pada penelitian ini telah dilakukan pembuatan benang fancy slub dengan beberapa variasi rangkapan yaitu 40 Tex (single slub), 82 Tex (rangkap 2), 124 Tex (rangkap 3), dan 162 Tex (rangkap 4) untuk bahan pembuatan kain gorden sebagai salah satu produk interior window covering. Penelitian ini bertujuan untuk mengetahui pengaruh perangkapan benang terhadap performa benang slub pada kain tenun yang akan digunakan untuk kain gorden. Mutu bahan kain untuk window covering dari benang fancy slub ini kemudian dibandingkan dengan syarat mutu kain gorden sesuai SNI 08-1275-2002. Dari penelitian ini dapat disimpulkan bahwa bertambahnya jumlah rangkapan pada benang slub berbanding lurus dengan Tpi dan kekuatan tariknya. Selain itu performa benang slub 162 Tex yang memiliki diameter benang paling besar dan twist paling tinggi yaitu 4,38 Tpi, menghasilkan efek slub yang cenderung samar, jika dibandingkan dengan benang slub 124 Tex dan 82 Tex yang terlihat lebih jelas. Berat kain untuk ketiga variasi benang slub tersebut masing-masing adalah $170,34 \mathrm{~g} / \mathrm{m}^{2}, 203,09 \mathrm{~g} / \mathrm{m}^{2}, 235,84 \mathrm{~g} / \mathrm{m}^{2}$ dan ketiganya masih sesuai dengan persyaratan mutu kain gorden (minimum $135 \mathrm{~g} / \mathrm{m}^{2}$ ). Hasil uji ketahanan luntur terhadap sinar terang hari pada ketiga variasi benang juga telah memenuhi persyaratan mutu yaitu minimum 4-5.
\end{abstract}

Kata kunci: benang slub, hias, gorden, tenun, kapas

\section{ABSTRACT}

In this study has been made fancy slub yarn with several variations of plies, namely slub yarn with yarn count 40 Tex (single slub), 82 Tex (2 plies), 124 Tex (3 plies), and 162 Tex (4 plies) for curtain fabric as an alternative for interior window covering product. This study purposed to determine the effect of yarn plies on the performance of slub yarn on woven fabric that will be used for curtain fabric. The quality of window covering material then compared with requirement quality of curtain fabric SNI 08-1275-2002. From this study, it can be concluded that the increasing number of slub yarn plies were directly proportional to Tpi and its tenacity. Besides that, the performance of slub yarn 162 Tex which had the largest yarn diameter and the highest twist 4,38 Tpi showed the slub effect tends to be vague, when compared to the slub 124 Tex and 82 Tex that were more clearly seen. Fabric weight for the three variation of the slub yarn respectively were $170,34 \mathrm{~g} / \mathrm{m}^{2}, 203,09 \mathrm{~g} / \mathrm{m}^{2}, 235,84 \mathrm{~g} / \mathrm{m}^{2}$, and they were still in accordance with the quality requirements of curtain fabric (minimum $135 \mathrm{~g} / \mathrm{m}^{2}$ ). The results of colourfastness to daylight on the three variations of slub yarn were still in accordance with the quality requirements that was minimum 4-5.

Keywords: slub yarn, fancy, curtain, weaving, cotton

\section{PENDAHULUAN}

Industri Tekstil dan Produk Tekstil (TPT) nasional telah melakukan berbagai inovasi dalam hal pengembangan produk, untuk menangkap peluang dari tren pasar global saat ini. Tekstil kini tidak hanya menghasilkan produk untuk kebutuhan sandang atau pakaian saja, tetapi berkembang menjadi industri tekstil non sandang. Produk tekstil telah dimanfaatkan untuk material tekstil interior, otomotif, medis, pertanian, infrastruktur jalan, dan lain-lain. Kementerian Perindustrian memproyeksi- kan komoditas industri tekstil non sandang ini memiliki peluang pasar cukup besar, rata-rata mencapai $9,9 \%$ per tahun dalam periode lima tahun terakhir, dengan kontribusi Indonesia mencapai $0,47 \%$ dari kebutuhan dunia. ${ }^{1}$ Inovasi dalam pengembangan produk tekstil sebagai material interior tentu saja sangat diperlukan untuk menangkap salah satu peluang tersebut. Seperti diketahui bahwa material interior merupakan elemen pembentuk interior yang terdiri dari lantai, dinding, dan plafon yang membentuk suatu ruang. 
Kebutuhan akan ruang yang aman dan juga nyaman dapat dipenuhi dari adanya produk pelengkap interior yang berkualitas. Kain untuk tekstil interior menurut kegunaannya, dikelompokkan menjadi kain pelapis furnitur/upholstery, kain penutup jendela/window covering, pelapis dinding/wall covering, dan pelapis lantai woven floor covering seperti karpet dan permadani. ${ }^{2}$ Terdapat beberapa tipe window covering yang sudah ada di pasaran, seperti gorden (curtain), drapes (tirai yang dilapisi lagi dengan kain sehingga lebih tebal dari gorden biasa), shade (tirai lipat yang menggunakan bahan pelapis dari kain) dan blinds. ${ }^{3}$

Pada penelitian ini window covering dibuat melalui proses pertenunan menggunakan benang lusi dari serat alam yaitu kapas dan benang pakan dari benang hias untuk memberikan tekstur khusus pada kain. Penelitian ini merupakan lanjutan dari penelitian "Aplikasi Benang Slub Pada Kain Tenun Tradisional". Pada penelitian tersebut benang slub baru diaplikasikan pada kain tenun sandang dan tanpa proses perangkapan dan penggintiran. ${ }^{4}$

Benang hias (fancy yarn) merupakan jenis benang tekstil khusus yang sengaja diubah karakteristik fisiknya menjadi tidak teratur. Karakter tersebut diantaranya adalah diameter, twist, warna, dan lain-lain sebagainya. Benang hias digunakan untuk mendapatkan variasi penampilan dan estetika yang menarik pada tekstil fesyen seperti denim, gorden, karpet, kain pelapis, dan sebagainya. ${ }^{5,6,7,8}$ Benang hias disebut juga benang khusus yang meningkatkan sifat visual dan tekstur kain. Benang hias dapat menggabungkan efek "cacat" yang disengaja dan pemberian warna untuk memberikan efek visual dan tekstur atraktif yang berbeda pada kain. Efek warna pada benang hias semakin terlihat dengan adanya proses penggintiran, pemintalan dan pencelupan benang hias dengan warna berbeda. ${ }^{9}$ Secara garis besar efek dekoratif berupa tekstur khusus yang dihasilkan oleh benang slub merupakan salah satu inovasi benang hias yang dapat diaplikasikan pada produk kain. ${ }^{10}$ Metode praktis untuk melihat pola pengulangan dari benang slub, salah satunya adalah dengan penggunaan papan hitam.

Benang slub adalah salah satu benang hias dengan beberapa bagian tebal pada benang (slub) yang dihasilkan melalui perubahan kepadatan linear benang secara sistematis selama proses pemintalan. ${ }^{11}$ Dari beberapa penelitian sebelumnya telah diketahui bahwa parameter utama benang slub seperti panjang slub, jarak slub, ketebalan slub, panjang benang dasar, nomor benang, twist, dan lain-lain berpengaruh terhadap kekuatan dan mulur benang. ${ }^{12,13,14}$ Dalam literatur lain terdapat beberapa penelitian lain yang menyatakan bahwa beberapa parameter dari benang slub yang digunakan sebagai benang pakan pada kain tenun memiliki efek yang signifikan secara statistik terhadap hasil uji kekuatan arah pakan pada kain tenun. ${ }^{13}$ Ditinjau dari twist dan sifat fisik dari benang slub, ternyata panjang slub adalah faktor kunci untuk menentukan twist benang. ${ }^{15}$ Diameter benang dasar, diameter slub, jarak slub dan panjang slub memiliki pengaruh terhadap distribusi twist, dan hal itu telah dikembangkan dengan model tertentu. Di sisi lain peningkatan ketebalan slub dapat menurunkan twist di bagian slub. Twist pada benang dasar selalu lebih dari twist teoritis benang slub, yang sangat dipengaruhi dengan rasio panjang slub terhadap jarak slub, dan peningkatan rasio akan meningkatkan twist di bagian benang dasar. Umumnya, kekuatan benang dipengaruhi lebih banyak oleh peningkatan kuantitas serat dalam benang dibandingkan dengan penurunan dalam twist slub. Kekuatan seluruh benang slub tidak jauh berbeda dengan benang dasar yang memiliki twist yang sama seperti benang dasar.

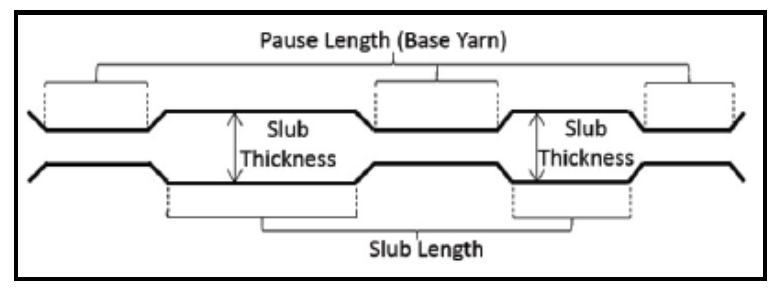

Gambar 1. Struktur benang slub ${ }^{16}$

Kecepatan rol draft membentuk slub yang terdistribusi secara teratur atau acak di dalam benang. ${ }^{17,18}$ Parameter penting dari benang slub termasuk panjang slub, jarak slub (panjang benang dasar), peningkatan massa atau penurunan massa dalam slub (ketebalan slub), ketebalan benang dasar dan pola pengulangan dari benang slub sebagaimana yang ditunjukkan pada Gambar 1 .

\section{METODOLOGI \\ Alat dan bahan}

Alat yang digunakan dalam penelitian ini adalah Mesin Creative Caipo Spin Tester, mesin pengelosan, mesin penggintiran, mesin penghanian, dan ATBM. Bahan yang digunakan adalah benang kapas 20 Tex dan roving kapas 856 Tex.

\section{Metodologi}

Metodologi penelitian dapat dilihat pada Gambar 2. Benang slub yang dihasilkan dari Mesin Caipo Spin Tester dibuat menjadi 3 variasi rangkapan yaitu rangkap 2, 3 dan 4. Proses tenun dilakukan menggunakan ATBM. Setelah itu dilakukan pengujian terhadap benang dan kain yang dihasilkan. Pengujian tersebut terdiri dari pengujian nomor, Tpi, kekuatan tarik dan mulur benang, ketahanan gosok kain, dan ketahanan luntur kain terhadap matahari. Pengujian ketahanan gosok dilakukan dengan alat Martindale Abrasion Tester. Kain contoh uji digosok pada Martindale Abrasion 
Tester dengan beban tertentu $(9 \pm 0,2 \mathrm{kPa})$ menggunakan media penggosok kain standar mengikuti gerakan yang membentuk gambar Lissajous.

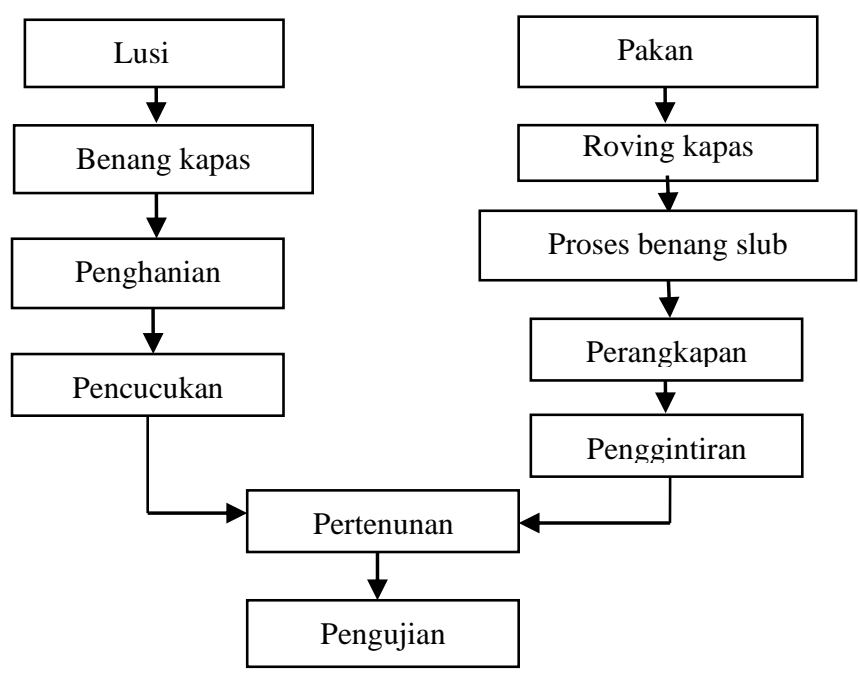

Gambar 2. Alur proses kegiatan penelitian

\section{HASIL DAN PEMBAHASAN \\ Hasil penelitian}

Dalam penelitian ini telah dihasilkan benang slub dengan menggunakan Mesin Creative Caipo Spin Tester. Proses pembuatan benang slub selama pengamatan berjalan lancar sesuai dengan program seperti yang diperlihatkan pada Tabel 1.

Tabel 1. Spesifikasi benang slub di mesin Caipo

\begin{tabular}{clc}
\hline No & Parameter & Nilai \\
\hline 1 & Program & 111 \\
2 & Panjang slub & $5 \mathrm{~cm}$ \\
3 & Panjang pause & $7 \mathrm{~cm}$ \\
4 & Thick & 3,00 \\
5 & Twist & $100 \%$ \\
6 & Input roving & $\mathrm{Ne} 0,69$ \\
7 & T Alpa & 3,5 \\
8 & Final count & $\mathrm{Ne} 15$ \\
9 & Slub coeffisiensi & 1,37 \\
10 & Draft & 29,89 \\
11 & Nominal twist & 15.89 \\
\hline
\end{tabular}

Tahapan proses selanjutnya dari pembuatan benang slub ini adalah pengelosan, perangkapan, dan penggintiran benang. Rangkaian proses ini bertujuan untuk menghasilkan diameter benang yang lebih besar sehingga diharapkan efek kain akan lebih bertekstur.

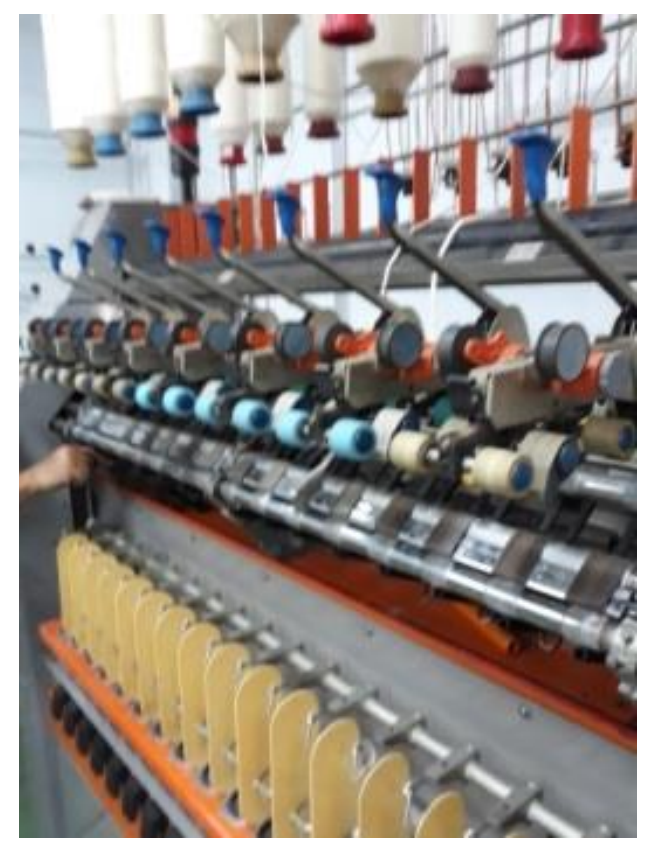

Gambar 3. Mesin Creative Caipo Spin Tester

Variasi benang slub yang telah dibuat dapat dilihat pada Tabel 2. Benang slub yang dihasilkan dari penelitian ini termasuk jenis benang slub periodik karena memiliki jarak dan panjang slub tertentu selama proses pembuatannya di Mesin Creative Caipo Spin Tester. 


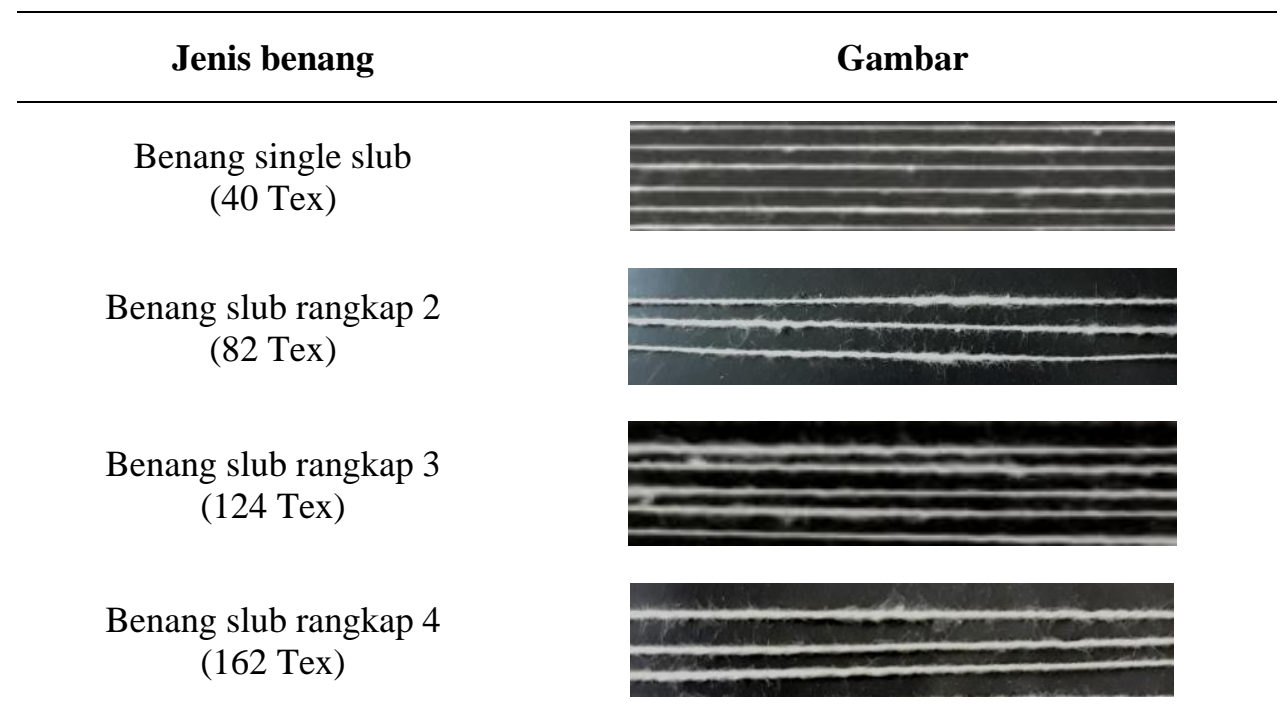

Gambar 4. Benang slub hasil perangkapan

Dari ketiga variasi tersebut terlihat bahwa benang slub rangkap 2 dan 3 memiliki diameter benang yang lebih kecil dari benang slub rangkap 4 namun efek slub masih terlihat jelas. Pada benang slub rangkap 4, diameter benang lebih besar namun efek slub terlihat samar.

Hasil pengujian nomor dan twist benang slub dapat dilihat pada Gambar 5.

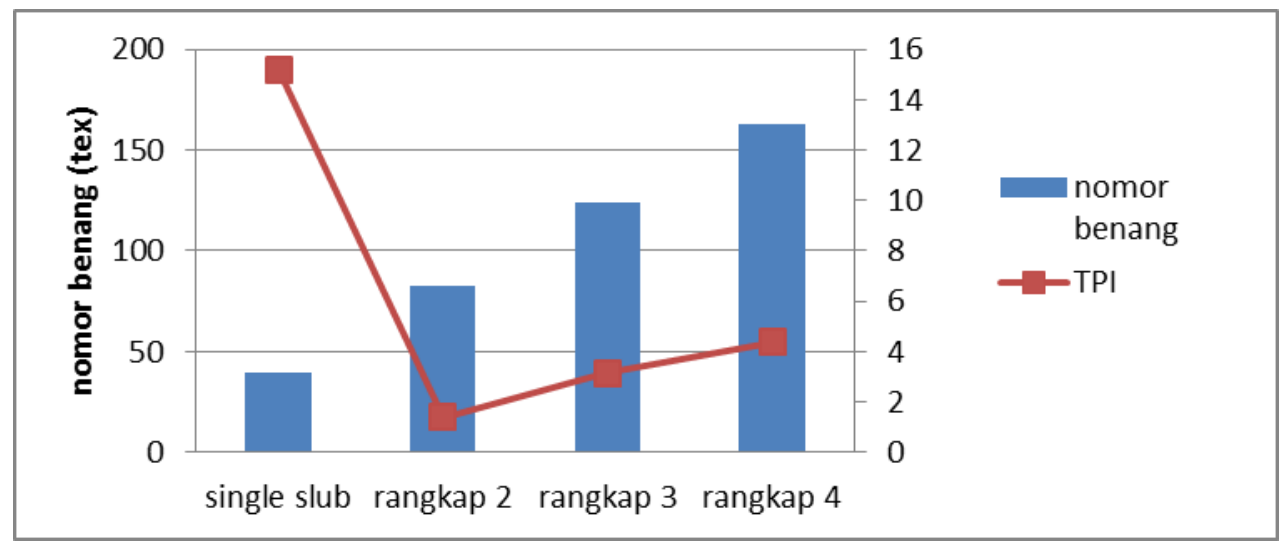

Gambar 5. Hasil uji nomor dan TPI benang slub

Dari hasil uji twist terlihat bahwa ukuran diameter benang slub berbanding lurus dengan twist benang yang dihasilkan. Hal ini juga yang menyebabkan efek slub yang dihasilkan semakin kurang terlihat (samar). Twist yang semakin tinggi menyebabkan efek gintiran menutupi permukaan benang lebih banyak sehingga bagian slub menjadi lebih padat. Seperti telah dijelaskan pada bagian pendahuluan bahwa twist pada benang sangat dipengaruhi dengan rasio panjang slub terhadap jarak slub. Pada penelitian ini benang slub mempunyai panjang slub $5 \mathrm{~cm}$ dan jarak slub (pause) $7 \mathrm{~cm}$. Rasio panjang slub terhadap jarak slub ini sangat penting karena akan mempengaruhi twist yang terjadi pada benang. Jarak slub yang lebih besar akan menghasilkan twist pada benang dasar yang lebih besar pula. Apabila panjang slub lebih besar dari jarak slub maka twist benang akan rendah dan akibatnya benang akan mudah putus. Untuk benang slub yang mengalami perangkapan, twist benang yang dihasilkan berbanding lurus dengan nomor benang slub. Benang slub tersebut kemudian ditenun sebagai benang pakan dengan menggunakan ATBM untuk melihat efek slub yang dihasilkan pada kain, dengan hasil seperti yang terlihat pada Gambar 6 . 

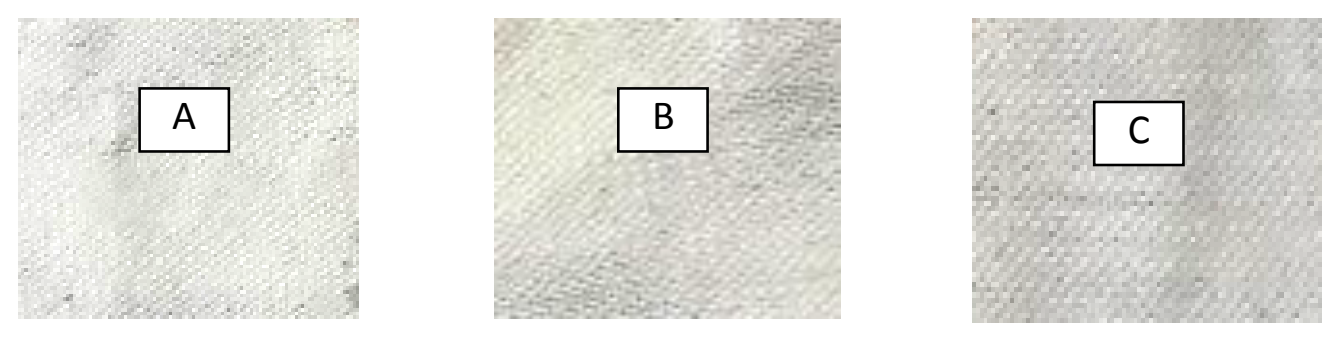

Gambar 6. Kain dengan variasi benang pakan slub rangkap 2, 3 dan 4

Kain dengan benang pakan slub rangkap 2 adalah kain $\mathrm{A}$, slub rangkap 3 adalah kain $\mathrm{B}$, dan slub rangkap 4 adalah kain C. Kain tersebut ditenun dengan benang lusi yang sama yaitu benang kapas 20 Tex. Jika dilihat dari performanya, ketiga variasi benang slub tersebut memberikan efek tekstur pada kain tenun. Dalam konteks desain tekstil, adalah penting menunjukkan "penyimpangan" yang disengaja untuk menampilkan karakteristik fisik dari benang slub tersebut untuk membuat kain tekstur yang berbeda. Pola perulangan pada benang slub dengan sistem periodik (jarak dan tebal yang beraturan) menghasilkan efek slub yang acak di kain. Hal ini disebabkan oleh pengaruh konstruksi kain, benang lusi, dan lebar kain yang mendistribusikan efek slub yang timbul pada kain tenun.
Penilaian mutu kain window covering dari benang slub ini mengacu pada persyaratan mutu berdasarkan SNI 08-1275-2002: Kain tenun untuk gorden. Definisi kain gorden menurut SNI 08-12752002 adalah kain tirai dengan konstruksi rapat yang tidak tembus pandang dan mempunyai sifat tertentu yang digunakan sebagai penutup jendela, pintu, dan sejenisnya. Window covering dapat dikategorikan sebagai tirai penutup jendela sesuai SNI tersebut. Berdasarkan data hasil uji kekuatan tarik, benang slub rangkap 4 memiliki kekuatan tarik yang terbesar dibandingkan benang slub lainnya yaitu 4,38 gram/Tex. Demikian pula untuk hasil uji mulur benang, terlihat bahwa mulur benang slub rangkap 4 lebih besar dibandingkan dengan benang slub yang lain yaitu 6,44\%. Data lengkap hasil uji kekuatan tarik dan mulur dapat dilihat pada Gambar 7.

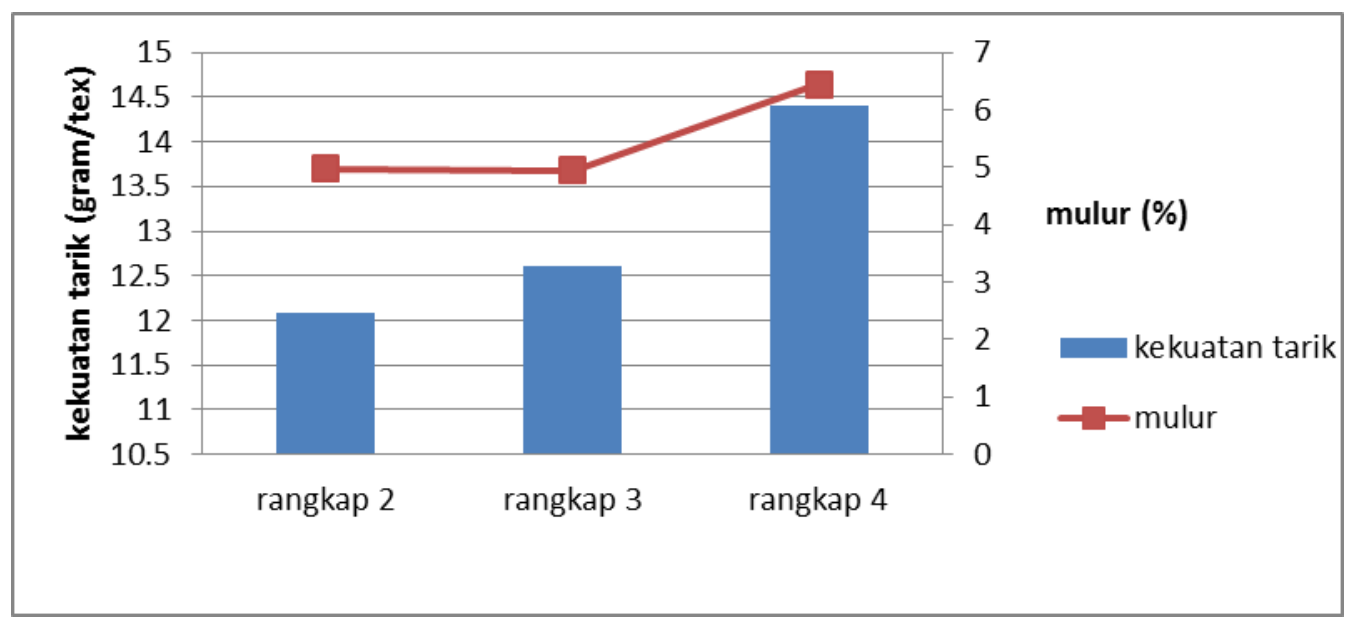

Gambar 7. Hasil uji kekuatan tarik dan mulur benang slub

Bila dibandingkan dengan Gambar 5 terlihat bahwa benang slub rangkap 4 dengan Tpi 4,38 memiliki kekuatan tarik tertinggi yaitu 14,4 gram/Tex. Dari data tersebut terlihat bahwa bertambahnya jumlah rangkapan berbanding lurus dengan Tpi dan kekuatan tariknya. Pada bagian pendahuluan telah dijelaskan bahwa kekuatan benang lebih dipengaruhi oleh peningkatan kuantitas serat dalam benang dibandingkan dengan penurunan twist pada slub. Pada gambar 5 dan 7 terlihat bahwa kuantitas benang yang lebih besar memberikan pengaruh terhadap twist benang slub dan kekuatan benang secara keseluruhan. Sifat-sifat mekanik benang tersebut berpengaruh juga terhadap performa benang yang dihasilkan. Tabel 3 memperlihatkan hasil uji tetal lusi, tetal pakan dan berat kain dari 3 variasi benang slub. 
Berdasarkan SNI 08-1275-2002 : Kain tenun untuk gorden, syarat mutu minimum berat kain adalah $135 \mathrm{~g} / \mathrm{m}^{2}$. Dari hasil uji ketiga variasi benang slub tersebut nilai berat kainnya memenuhi persyaratan mutu kain gorden.

Tabel 2. Tetal lusi, pakan dan gramasi kain

\begin{tabular}{ccccc}
\hline No. & Variasi kain & Tetal lusi (helai/inci) & Tetal pakan (helai/inci) & $\begin{array}{c}\text { Berat kain } \\
\left(\text { (gram/meter }^{2}\right)\end{array}$ \\
\hline 1. & Kain A & 30 & 43 & 170,34 \\
2. & Kain B & 30 & 38 & 203,09 \\
3. & Kain C & 30 & 33 & 235,84 \\
\hline
\end{tabular}

Pengujian lain untuk menilai mutu kain window covering adalah ketahanannya terhadap gosokan berulang. Hasil uji menunjukkan bahwa jumlah rangkapan benang slub berbanding lurus terhadap nilai ketahanan gosok kain tenun yang dihasilkan. Pada kain A kerusakan contoh uji terjadi setelah gosokan ke 12.650 kali, pada kain B contoh uji rusak pada gosokan ke 19.000 kali, sedangkan untuk kain $\mathrm{C}$ kerusakan contoh uji terjadi setelah gosokan ke 22.500 kali.

Tabel 3. Hasil uji ketahanan luntur warna terhadap sinar terang hari

\begin{tabular}{ccc}
\hline No. & Variasi kain & Nilai \\
\hline 1. & Kain A & $>4$ \\
2. & Kain B & $>4$ \\
3. & Kain C & $>4$ \\
\hline
\end{tabular}

Berdasarkan SNI 08-1275 syarat mutu ketahanan luntur terhadap sinar terang hari minimum adalah 4-5. Dari hasil uji sebagaimana tercantum pada Tabel 3 maka ketiga variasi benang slub tersebut memiliki nilai tahan luntur warna terhadap terang hari yang telah memenuhi mutu kain gorden.

\section{KESIMPULAN}

Dari penelitian ini dapat disimpulkan bahwa benang fancy khususnya benang slub dapat diproses di Mesin Creative Caipo dengan program yang bervariasi. Berdasarkan hasil pengujian benang slub tersebut dapat diaplikasikan pada kain tenun untuk menjadi bahan pembuatan window covering. Performa benang slub 124 Tex dan 82 Tex memiliki diameter benang lebih kecil dari 162 Tex namun menghasilkan efek slub yang masih terlihat jelas. Pada benang slub 162 Tex, diameter benang paling besar namun efek slub terlihat samar. Dari hasil uji kekuatan tarik, benang slub rangkap 4 memiliki kekuatan tarik yang terbesar dibandingkan benang slub lainnya yaitu 4,38 gram/Tex. Dari hasil uji Tpi dan kekuatan tarik benang terlihat bahwa bertambahnya jumlah rangkapan pada benang slub berbanding lurus dengan kekuatan tariknya. Sedangkan untuk syarat mutu berat kain untuk ketiga variasi benang slub tersebut masih sesuai dengan persyaratan mutu kain gorden yaitu minimum $135 \mathrm{~g} / \mathrm{m}^{2}$.

Hasil uji ketahanan gosok kain metode Martindale dengan cara uji kerusakan contoh uji menunjukkan hasil bahwa jumlah gosokan tertinggi terdapat pada kain dengan benang slub 162 Tex yaitu 22.500 kali. Hasil uji ketahanan luntur terhadap sinar terang hari terhadap ketiga variasi benang slub sesuai dengan mutu kain gorden, yaitu dengan nilai $>4$.

\section{PUSTAKA}

1. https://katadata.co.id diakses tanggal 14 Agustus 2019

2. Eko Prasetyo Kuslambang, dkk, (2019), Eksperimen potensi kain serat pisang sebagai material produk pelengkap interior. Jurnal Intra Vol. 7 No. 2, 954-963

3. Michelle Ullman (2019). A guide to the most common types of window treatments, The Spruce Home Decoration

4. Yusniar Siregar, Mochamad Sahid Alamsyah, Moekarto Moeliono (2015). Aplikasi benang slub pada kain tenun tradisional, Arena Tekstil Vol. 30 No. 2

5. Grabowska, K. E., Ciesielska, I. L., and Vasile, S., (2009). Fancy yarns-an appraisal. AuTex Research Journal, 9(3), 82-81.

6. Petrulytè, S., (2003). Complex structure fancy yarns: theoretical and experimental analysis. Materials Science 9(1), 120-123.

7. Ureyen, M. E. and Kadoglu, H., (2007). The prediction of cotton ring yarn properties from afis fiber properties by using linear regression 
models. Fibres and Textiles in Eastern Europe, 15(4), 63-67.

8. Jihong, L., Zhenping, X., Weidong, G., and Hongxia, J., (2009). Automatic determination of slub yarn geometrical parameters based on an amended similarity-based clustering method. Textile Research Journal, 80(11), 1075-1082.

9. P.K. Hari.(2012).Types and properties of fibres and yarns used in weaving, Woven Textiles, Principles, Technologies and Applications. Woodhead Publishing Series in Textiles

10. Hajer Souid, et al. (2008). A Comparative quality optimisation between ring spun and slub yarns by using desirability function, AuTex Research Journal, Vol. 8, No3, 72

11. Lu, Y., Gao, W., and Wang, H., (2007). A model for the twist distribution in the slub-yarn. International Journal of Clothing Science and Technology, 19(1), 36-42.

12. Muhammad Bilal Qadir, et al Response surface modeling of physical and mechanical properties of cotton slub yarns. AuTex Research Journal, DOI: 10.1515/aut-20170025

13. Souid, H., Babay, A., Sahnoun, M., and Cheikrouhou, M., (2008). A comparative quality optimization between ring spun and slub yarns by using desirability function. AuTex Research Journal, 8(3), 72-76.

14. İlhami İlhan, Osman Babaarslan, Deniz Vuruşkan (2012). Effect of descriptive parameters of slub yarn on strength and elongation properties. Fibres \& Textiles in Eastern Europe; 20, 3(92): 33-38.

15. Mahmood N, Arshad M, Iftikhar M, Mahmood T. (2009). Technological study of ring and compact spinning systems for the manufacturing of slub fancy yarn under multiple slub variations and its effect on woven fabric, Pak. J. Agri. Sci.,; 46(2).

16. Xiuping, L., Zhijie, W., Zhixun, S., and Choi, K. F., (2008). Slub extraction in woven fabric images using gabor filters. Textile Research Journal, 78(4), 320-325.

17. Md. Abid Hasan. (2017). A comparative study between lycra integrated slub (LIS) yarn and normal slub yarn produced in same ring spinning frame. International Journal of Scientific \& Engineering Research Volume 8, Issue 11

18. Jun, W. and Xiubao, H., (2002). Parameters of rotor spun slub yarn. Textile Research Journal, 72(1), 12-16 
Arena Tekstil Vol. 34 No. 2, 2019 : 93-100 